\title{
家兔右房標本を用いた各種抗不整脈薬に伴う 催不整脈作用の検討
}

$\begin{array}{lllllll}\text { 沢 } & \text { 登 } & \text { 徹*1 安谷屋 均*2 庄 司 敏*2 } \\ \text { 平 岡 昌 } & \text { 和*2 } & & & \end{array}$

はじめに

抗不整脈薬は抗不整脈作用以外に催不整脈作用 を引き起こすことが知られている ${ }^{12)}$ 。この催不 整脈は薬剤投与後、新たな種類の不整脈の出現や 存在した不整脈の持続時間、出現頻度、心拍数の

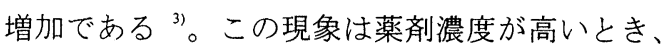
心筋が障害を受けているとき、心筋細胞を取り巻 く環境の変化の際に多く認めるが、治療濃度時で

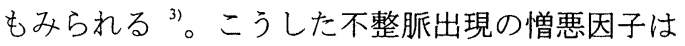
なお十分解明されていない。今回、比較的健常に 近い標本で、同一条件で旋回性不整脈が出現する 条件や治療濃度の抗不整脈薬投与後の、不整脈誘 発頻度を観察し、増悪因子を検討した。

[方法］家兔（3〜3.5kg）の耳静脈に Na-ペン ドバルピタール $(50 \mathrm{mg} / \mathrm{kg})$ を投与して麻酔後、 大動脈にカニュレーションして、ランゲンドルフ 潅流を行いながら、右心房内膜面、crista terminalis の輪状構造を含む標本を作成した。電極は洞結節 及び房室結節近傍に微小電極を刺入、前結節間経 路や後結節間経路上に双極電極を置き記録した。 なお、頻拍の誘発には、期外刺激法を用い、洞結 節近傍領域より 8 拍の基本刺激 $(\mathrm{CL}=350 \mathrm{~ms})$ 後 に $300 \mathrm{~ms}$ より $10 \mathrm{~ms}$ 毎に短縮させた期外刺激を与 えて、抗不整脈薬投与前後の不整脈誘発の有無及 び誘発された頻拍の持続時間を調べた。

\footnotetext{
*1 東京医科歯科大学難治疾患研究所情報医学研究部門 臨床薬理学

于 101-0062 東京都千代田区神田駿河台 2-3-10

*2 東京医科歯科大学難治疾患研究所成人病疾患部門循 環器病
}

使用した抗不整脈薬はジソピラミド $(1-10 \mu$

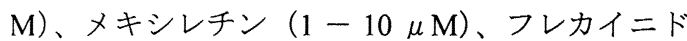
$(10-100 \mu \mathrm{M})$ 、セマチリド $(10-100 \mu \mathrm{M}) 、$ ベプリジル $(2-10 \mu \mathrm{M})$ である。

[結果］摘出した右房標本で何も操作しない状 態下では、期外刺激による頻拍は 39 例全例に認 めなかった。標本上の前又後結節間経路内側のい ずれかに $1 \sim 2 \mathrm{~mm}$ 程度の切開を加えた状態では 非持続性（echo beats が 9 拍以下）持続性頻拍 (echo beats が 10 拍以上) は 31 例中 19 例（61 \%）認め、その頻拍の様式は前結節間経路の障害 では反時計方向、後結節間経路の障害では時計方 向の傾向を示した。誘発した頻拍のうち $70 \%$ は 30 拍以上、 $30 \%$ \%がれ下であった。 $\mathrm{K}=4.0$ よ り $6.8 \mathrm{mM}$ の高カリウムでは頻拍の出現を認めな かったが、結節間経路の一部に上記と同様な障害 を加えると、12 例中 8 例 $(67 \%)$ に頻拍の出現 を認めた。不态期の不均一を作るアセチルコリン 単独投与では 6 例中 3 例 $(50 \%)$ に頻拍を認め るが、経路に障害を加えると 15 例中 13 例（89 \%）と頻拍の出現頻度は増加した。頻拍の誘発に は種々の方法があるが、今回、結節間伝導路のみ の障害による方法を用い、臨床血中濃度に近い各 種抗不整脈薬の作用を検討した。投与後 $5 \sim 10$ 分では期外刺激による頻拍の持続時間が増加し、 憎悪した例はジソピラミド $(1 \mu \mathrm{M}) 4 / 5(80 \%) 、$ メキシレチン (1 $\mu \mathrm{M})$ 0/6（0％)、フレカイニ

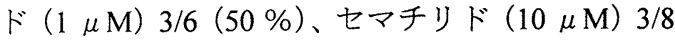
(37.5％)、ベプリジル $(1 \quad \mu \mathrm{M}) \quad 0 / 5(0 \%)$ で あり、15〜30 分後ではいずれの薬剤も期外刺激 
による頻拍の誘発は認められなくなった。薬剤濃 度を高くすると憎悪例は減少ないし抑制された が、ベプリジル（10 $\mu \mathrm{M} ）$ では $1 / 5 （ 20 \%)$ に憎 墨例を認めた。有効不応期（EPR）の不均一性を みるとジソピラミドは対照 $27.5 \mathrm{~ms}$ 、憎悪例 $45.0 \mathrm{~ms}$. と増加したのに対して、抑制例では対照 $18.0 \mathrm{~ms}$ に対して $22.0 \mathrm{~ms}$ と変化をみなかった。フレカイ ニドは対照 $33.2 \mathrm{ms、}$ 、憎悪例 $20.0 \mathrm{~ms}$ であり、抑制 例は対照 $41.6 \mathrm{~ms}$ に対し $18.3 \mathrm{~ms}$ と減少が大きかっ た。時間経過における有効不応期はジソピラミド 投与 5 分で $7.5 \%$ 延長、 15 分で $18 \%$ 延長、フレ カイニド 5 分で $13 \%$ 延長、 15 分では $37.3 \%$ 延長、 セマチリドでは 5 分で $15.8 \% 、 15$ 分で $39.4 \%$ の 延長を認めた。エコーゾーンと不応期の関係を比 較した。一般に薬剤投与後の不応期の延長がエコ ーゾーンを含む程に延長すれば完全に不整脈の誘 発は抑制される。頻拍誘発憎悪例では薬剤投与前 に比較し、投与後に不応期の值とエコーゾーンの 最小値との差は大きくなった。

[考察] 家鬼右房標本では単一期外刺激による旋 回性頻拍の誘発は困難であった。しかし旋回経路 上に局所的障害を加えることや、アセチルコリン を投与することで頻拍の誘発は可能であった。 Brugada 等"は家兔心に単一期外刺激では心室頻 拍を認めないが、3 連発ないしバースト刺激を与 えることで頻拍が出現すると報告している。高力 リウム状態にした場合、頻拍の誘発は困難で、局 所的障害の付加が必要であった。またアセチルコ リンの投与でも局所障害を加えることで頻拍誘発 の頻度はさらに増加した。このことは頻拍誘発の 要因に局所的伝導障害或いは不応期の不均一が挙 げられる。

旋回経路上に障害を加えた状態で、臨床使用濃 度の抗不整脈薬投与 $5 \sim 10$ 分後でジソピラミド、 フレカイニド、セマチリドは投与前に比し誘発頻 拍の持続時間の延長を認めたが、ベプリジル、メ キシレチンはいずれも頻拍の誘発は認めなかっ た。しかし頻拍の誘発を認めた薬剤も $15 \sim 30$ 分 ではすべて頻拍誘発は困難となった。この説明に 投与薬剂に対する細胞反応の均一化に多少の時間 が必要とも考えられる。Carlsson ら ${ }^{4}$ は家鬼の耳
静脈より異なる速度で薬剤を投与すると、QTc の 不均一は速い速度の投与で大で、しかも不整脈の 発生が高いことを報告した。我々は同一速度で、 異なる薬剤濃度を投与したが、結果は治療濃度で 催不整脈作用がみられ、濃度が高く、投与時間が 長い程、頻拍誘発が抑制された。治療濃度でも催 不整脈は認めるが、薬剤濃度と催不整脈の関係は 示されていない 5)。薬剤投与早期の ERP の不均 一性は対照に比べ憎悪例で大きく、伝導時間は対 照に比し軽度の変化であった。Dhein ら ${ }^{6}$ は摘出 家鬼心の心室表面の興奮波の広がりを調べ、抗不 整脈薬投与後に興奮過程の異常を認め、催不整脈 作用の程度はフレカイニド>ジソピラミド>メキ シレチン、リドカインの順であることを報告した。 以上より不整脈誘発の憎悪因子は単一のものでな く薬剤濃度や投与の時間経過に伴う伝導及び有効 不応期の変化が関係すると考えられた。 文献

1) Brugada, P. and Wellens, HJT. : Arrhythmogenesis of antiarrhythmic drugs. Am. J. Cardiol., 61:1108-1111(1988)

2) Podrid, PJ. : Aggravation of arrhythmia : A complication of antiarrhythmic drug therapy. Eur. Heart J., 10 (suppleE) :66-72 (1989)

3) Velebit, V., Podrid, P. and Lown, B. et al. : Aggaravation and provocation of ventricular arrhythmias by antiarrhythmic drugs. Circulation., 65:886-894 (1982)

4) Carlsson, L., Abrahamsson, C. and Andersson, B., et al. : Proarrhythmic effects of the class III agent almokalant, importance of infusion rate, QT dispersion, and early afterdepolarizations. Cardiovasc Res., 27:2186-2193 (1993)

5) Roden, DM., Woosley, PL. and Kirbyprimm, R. : Incidence associated long QT syndrome : implications for patient care. Am. Heart J., 111:1088-1093 (1986)

6) Dhein, S., Muller, A. and Gerwin, R. et al. : Comparrative study on the proarrhythmic effects of some antiarrhythmic agents. Circulation., 87:617-630(1993) 